\title{
A JOKE, MOCKERY, OR SOMETHING MORE? THE CHURCH OF THE FLYING SPAGHETTI MONSTER - AN INVENTED RELIGION OR A NEW MOVEMENT?
}

\author{
Siarhei A. Anoshka \\ Lecturer, PhD student in the field of theology of religion \\ Faculty of Theology, Department of Religious Dialogue \\ Cardinal Stefan Wyszyński University in Warsaw, Poland \\ anoshka@email.ua
}

\begin{abstract}
This article attempts to analyse a contemporary phenomenon from the sphere of alternative religiosity in the form of joke religions. The main subject of the analysis is a new religious movement called the Church of the Flying Spaghetti Monster (CFSM), founded in the USA in 2005. By referring to the theory of carnival fun, joining the sacrum and profanum, and passing through the various doctrinal threads of this religious movement, the author attempts to answer the question of whether the CFSM can be considered a genuine religion or only a joke.

The article begins with a short reflection on the possibility of joking about religion and faith, and the response to religious humour by people of faith, which may range from anger to disgust and sometimes even to aggression. Then, after a short history of this new (pseudo-)religious movement, a perspective is developed. It emerges that the whole structure of the so-called doctrine of this (quasi-)religion refers to other known religions and beliefs, including other new religious movements.
\end{abstract}

Keywords: alternative religiosity, Church of Flying Spaghetti Monster, humour, joke religion, new religious movements, Pastafarianism, quasi-religion, sacrofanum

\section{INTRODUCTION}

The concept of monotheistic religion is rarely associated with what is funny. Rather, religion pertains to the state of communing with the holy. The spiritual experiences associated with participation in religious life leave no place for joking. Making fun of religion or parodying it is a form of profanation, bringing the sacred element to the secular sphere, or even humiliating it (Nowicki 
2011: 57). Thus, humour and laughter sometimes seem amoral (McDonald 2012: 92) or even distressing to the targets being ridiculed (Kozintsev 2015: 4). As V. Saroglou writes, "it implies an arrest of moral judgement" (2002: 191-214). This may be why in the fifteenth century the faculty of theology in Paris issued a letter to the prelates of France, expressing abhorrence and execration regarding a certain kind of ritual merriment called the Feast of Fools. The origins of the feast lay in ancient pagan rites, the festum fatuorum, condemned long ago by the apostle Paul, as well as St. Augustine (Harris 2011: 1-7). In polytheistic religions, the absence of humour does not seem to be obligatory, because in such religious systems we encounter divine mirth, for example in Shinto (Laude 2005: 119) or in the Chinese and Japanese forms of Zen Buddhism (Gilhus 2004 [1997]: 132-133).

Analysing humour in the widest perspective, we should pay attention to the fact that humour depends on the cultural context in which it arises (Rynkiewicz 2012: 85). After World War II, humanity began searching for different patterns of belief, which resulted in, among other things, the emergence of new religious movements. Among them were jokes disguised as religions (or religions disguised as jokes). This phenomenon is part of a paradigm shift, with spoof religions being associated with the ideas of postmodernism, in which there is no simple reference to the sacrum (Ulmer 1985: 92).

In the humanities, both in studies of religion as well as in sociology or theology of religion, this phenomenon has different names and definitions. One scholar in the field of comparative religion, D. Chidester, proposed the designation authentic fakes, because they have authentic features familiar from religion, while at the same time simulating religion, which is why they are a falsification (Chidester 2005). Richard L. Smith called them neophilic irreligions, A. Possamai calls them hyper-real religions (Geoffroy 2012: 23), while the Australian historian of religion C. M. Cusack stated that they are simply invented religions (Cusack 2010). This is a completely new type of religiosity, and religious parody. Movements mocking religion can become new areligious or even new atheistic movements. Although most scientists do not take invented religions seriously, they can be considered functionally similar, if not identical to traditional religions (Mikhelson 2018: 130). Such movements may also be labelled cyber-religions, hyper-real religions or fake cults (Obadia 2015: 117).

In the twentieth and twenty-first centuries, an interesting phenomenon appears within the protest movement in the West, one that tries to present serious fundamentals in a playful or even comic manner. Gaming forms of protest are usually non-violent, although, despite their parodixical-comic character, they can provoke feelings of dislike or even aggression in society. It is no secret that such protest forms are now international in character, present both in 
the Western Hemisphere and in the post-Soviet space, in the former so-called "countries with victorious socialism" (Moddelmog-Anweiler 2017: 114). Often, protest movements began to take the form of carnival in its original meaning, when discontent and social tension were expressed in society with the help of game instruments, and, accordingly, were not real, but were only the likeness of discontent and tension. And what could be more pleasant than humour, jokes, and the possibility of presenting a serious subject comically or as parody?

In the carnival culture of the Middle Ages, whence the phenomenon now known was born, laughter and jokes were of immeasurably great significance. With the help of humour, there was a reduction in social tension; overcoming fears, in fact, the world was, as it were, born, or at least updated (Lochrie 2016: 67). In this rather harsh period of a rigidly structured society, when any violation of the rules was strictly punished by both the church (laughter was something that mocked heaven) and the state and even by ordinary public opinion, as we now call it, the carnival approach provided an opportunity to see as a friend or equal one whome we might normally see as a superior. Thanks to the ability of jokes to relieve tension, allowing one to make fun of things that would otherwise be frightening, humour turns a grim reality into something worthy of ridicule, and therefore makes it easier to bear.

Many such jokes are not strictly connected with faith or religion but rather with archetypal characters of citizens or clergy (Davies 1998: 61). The carnival allowed people not only to become entangled in new roles but also to play tricks on others, as well as on themselves, without fear of punishment or conflict. Russian linguist and literary critic, M. Bakhtin, saw the carnivals of Medieval Europe as occasions during which the authority of the state and the church were temporarily inverted. One such carnival did not coincide with any commemoration of sacred history but marked the last days before Lent (Bakhtin 1984: 8).

Bakhtin recognises that the tradition of carnival dwindled in Europe following the Renaissance (Bakhtin 1984: 218-219). In the modern world, carnival has lost its purpose and banter, irony and humour are not always adequately perceived in society, especially if the topic is serious, for example worldview, faith, and religion.

In this article I would like to focus on a concrete example, a case study of today's form of carnival entertainment in the field of religion. This is a new religious movement (or quasi-religious movement) known as the Church of the Flying Spaghetti Monster (the CFSM), or Pastafarianism. Carnivalesque as well as playing with the sacred is inherent in the CFSM because its attributes and symbols parody Christian symbols, thus being something like sacred parodies, the so-called parodia sacra (Burde 2010: 231) that were played during the carnival (Russian Maslenica) and Easter carnivals. 


\section{THE BEGINNINGS OF THE CFSM MOVEMENT}

Pastafarianism is a so-called new religion (Pawluczuk 1990: 32) that appeared at the beginning of the twenty-first century in the USA, a country where, with a few exceptions, most joke-religions were born (Nowicki 2011: 60). The founder of this quasi-religious movement is a young physician, Bobby Henderson, who was born in 1980 (Obadia 2015: 121). ${ }^{2}$ In 2005 a Kansas court decision required the introduction of a school course called Intelligent Design as an alternative to evolutionary teaching (Beckwith 2003: 160-161). ${ }^{3}$ Henderson proposed the introduction of a course about a new religion that he had created.

Pastafarianism began when Henderson sent an open letter to the Kansas Board of Education in June 2005 in response to the debate on whether to give the theory of intelligent design (ID) equal time with the theory of evolution in biology lessons. On his site, venganza.org, the name of which comes from the Spanish word for 'revenge' (Kamiński 2015: 37), Henderson formally demanded equal time to teach classes on the Flying Spaghetti Monster (Fig. 1) (Pittman 2016: 242$)^{4}$ as the creator of the Universe ${ }^{5}$ - the same as for the other versions of the theories of intelligent design and evolution. He warned that if his request was not met, he would be forced to take legal action. This drew attention to the problem that if the teaching of any religion is to become compulsory in schools, then choosing one of them could provoke opposition from others. Members of the Kansas Board of Education generally responded favourably, saying that such humour is needed in times of serious debate (Nowicki 2011: 78).

The venganza.org site (Beckford \& Demerath 2007: 360) ${ }^{6}$ gained more attention when the Boing Boing portal mentioned it in June 2005. The portal announced that it would pay $\$ 250,000$ to anyone who could prove that Jesus was not the son of the Flying Spaghetti Monster (Limelie 2014: 21-22). Website traffic also increased in August 2005

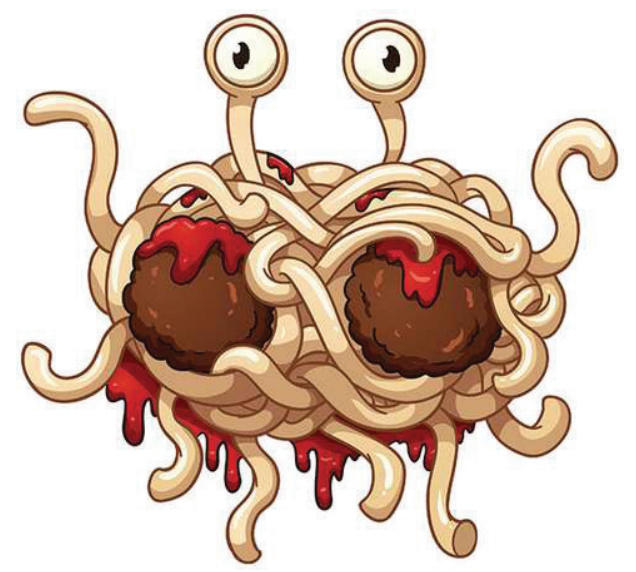
when information about the FSM began to appear in online blogs.

Figure 1. Flying Spaghetti Monster. An artist's rendition of the Flying Spaghetti Monster. (C) Memo Angeles / Shutterstock.com. 
The idea of faith in the Flying Spaghetti Monster is to spread tolerance and common sense among people (Fang 2014: 230; Grobler 2014: 191). Monster followers do not submit to any regulations or orders. The approach to the faith of each of the followers is individual, they do not perform any rituals, masses or prayers. Faith is based on certain basic elements. The world was created by the Flying Spaghetti Monster who began the process, starting with mountains, trees, and dwarfs. Anyone who calls for evidence for evolution is wrong - they were planted by the Monster (Henderson 2006: 33).

In the Gospel of the Flying Spaghetti Monster, published in 2006, there are many elements typical of beliefs known from other religions, for example:

- Believing that your own theory is "probably" true, and the theories of others are false. According to Henderson, other religions are not bad, but their followers are wandering. However, they can always convert to Pastafarianism. Unfortunately, this is not possible for believers from some other religious systems, for example Scientologists (Sieradzan 2013: 30).

- It is a peaceful religion, which is best for everyone.

- Faith in the FSM as the Creator of the world. The FSM is the first cause and is the source of life. It is hidden, invisible, benign, and omniscient.

- Belief in hell: hell resembles heaven with the difference that beer is stale, and strippers (as in Las Vegas, which Henderson emphasises) carry venereal diseases (Dooling 2008: 224-225).

\section{THE DOCTRINE OF THE CFSM AND ITS CONNECTIONS WITH OTHER RELIGIOUS TRADITIONS AND BELIEFS}

What is the religious manifestation of this movement? After all, if Pastafarians want to consider themselves religious believers, an integral part of the doctrine must be a religious dogma - an external expression of inner experiences associated with religious experience.

The sacred food for all Pastafarians is macaroni, which all believers should eat-Henderson claims that pasta is "food for the soul" (2006: 46). Here one can observe the first element of parody: instead of the Holy Communion (Eucharist) ${ }^{7}$ of the Christian tradition, Pastafarians eat the body of their 'god'. Some scholars perceive it as a moment when the 'cult' is developing roots in an historical era in which plenty of food is perceived as a cult of abundance and wealth, including at the religious level.

Let us return for a moment to the theory of carnival. During the feast, food becomes almost sacred, food becomes something of a fetish for the people 
involved in this action. The abundance of food is not only an image of new life and victory of life over death, but also has a sacred significance, being an attribute of a heavenly place (Tiaglova 2014: 18-19). Some researchers who are familiar with the Christian tradition and the Bible in particular, might quote the Old Testament: "On this mountain the Lord of hosts will make for all peoples a feast of rich food, a feast of well-matured wines, of rich food filled with marrow, of well-matured wines strained clear" (Isaiah 25:6). The dishes and drinks on the table were prepared by God Himself, so we can expect them to be better than what man makes. However, when we read further, we see that on the table there are greasy foods and wine, against which the Holy Bible warns us many times.

When the Bible was written, wine and fatty foods were considered some of the best dishes for the Israelites. The act of eating in the archaic consciousness is an important element of the cosmogonic act. This view emerges in the age of totemism, in which society and the surrounding light were 'contained', and reappeared in the act of eating. A joint meal, the act of eating food, can thus have the character of a sacrifice, during which 'death' and the subsequent 'resurrection' of the food object - totem, god - takes place. In the image of the Spaghetti Monster, a certain dualism is seen: on the one hand one can observe the cult of food, its abundance, and on the other, ridiculing this approach, a parody of the cult of plenty. For Pastafarians even the Tower of Babel (in the CFSM the Tower of Scrapple) is a tower of food leftovers (Henderson 2006: 74-75).

Proofs of the existence of the Spaghetti Monster are built in a comic form and make fun of creationism. ${ }^{8}$ At the same time, it is important in Pastafarianism to reduce the slogans, actions, and acts of evidence to absurdity (Dyadushkin 2013: 13-14), thereby demonstrating the frivolity of their own intentions. An example of such reductio ad absurdum is Bobby Henderson's inclusion in the 'theology' of his church of the concept of piracy. In a letter to the Kansas Board of Education, Henderson argues that reducing the number of pirates in the world leads to global warming (Obadia 2015: 124). ${ }^{9}$ In this absurd example and inference, the young American physician wants to show that the relationship between the number of pirates and global warming is not equal to causality (Kamiński 2015: 41-42).

In this case, the use of the image of the pirate and piracy in Pastafarianism is quite interesting. According to the teachings of this 'church', pirates are the chosen people, they proclaim the word of the Spaghetti Monster, give out sweets to children, and make geographical discoveries. Historically, their image was changed, and therefore persecution of pirates began (Henderson refers to the eras of Antiquity and the Middle Ages). But since the era of Romanticism, the image of pirates has changed for the better, mainly thanks to literature. The 
Figure 2. Propaganda Materials of the FSM Church. (C) Steven Klingers, coloured by Yves Forban 2013.

pirate embodied the ideals of freedom, nobility, and a gentlemanly nature. The best example could be seen in the movie saga Pirates of the Caribbean (Tiaglova 2014: 19-20).

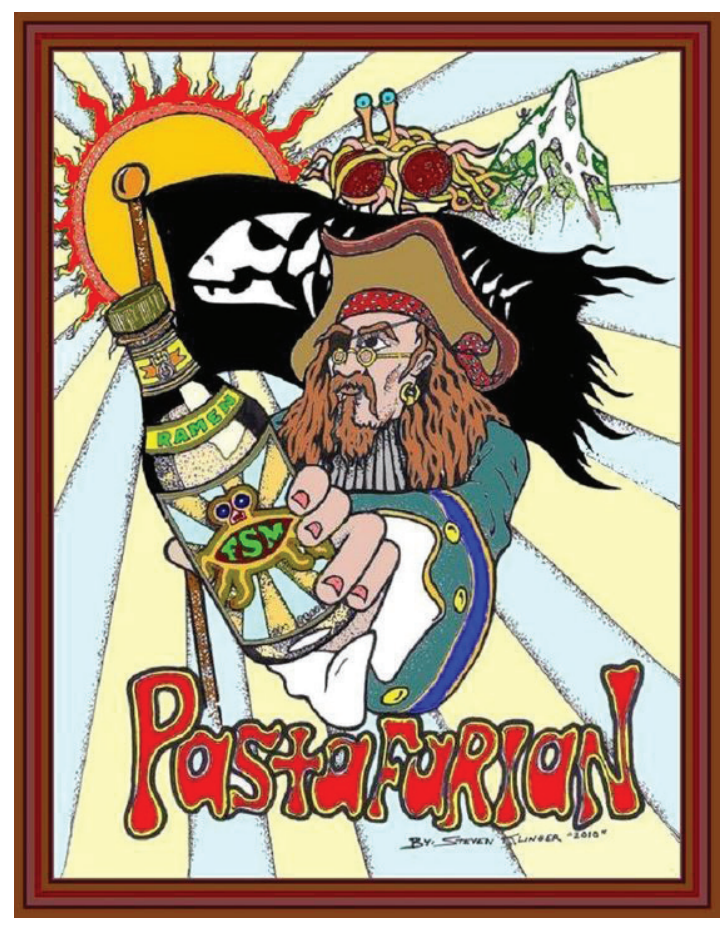

Because Pastafarianism recognises pirates as almost sacred (Cusack 2012: 307), ${ }^{10}$ the prophet Bobby plans to build a pirate ship from funds obtained from the sale of his book on the Flying Spaghetti Monster and religion-related issues (Smarsh 2010: 128). The image of the pirate Jack Sparrow has ambivalent features, for example, an archaic evil and at the same time a charming personality. The doctrine of the pirates in the Church of the Flying Spaghetti Monster contains an element of travesty, that is, the comic concept of carnival. ${ }^{11}$

Despite the seemingly humorous underpinnings of the whole doctrine, representatives of this movement convince us that they believe in this quite seriously. Pastafarians believe that people originated from pirates ${ }^{12}$ and that they will find broadband Internet and trees on which small kittens grow in heaven. Heaven for each Pastafarian is simple, consisting of elements that every admirer of the Flying Spaghetti Monster considers heaven for him- or herself. You will be able to move through the advanced system of gryphon air transport, by turning into a bird or dragon, and will enjoy entertainment such as swamps of hot chocolate, rivers of lemonade, and beer volcanoes. ${ }^{13}$

The concept of heaven in the CFSM could be a parody of the eschatological doctrine of Islam: paradise, according to the Spaghetti Monster, features a Stripper Factory, in which we can see humorous scoffing at the promise of paradise for Muslims, filled with 72 houris (Aarde 2013: 36). Admittedly, 


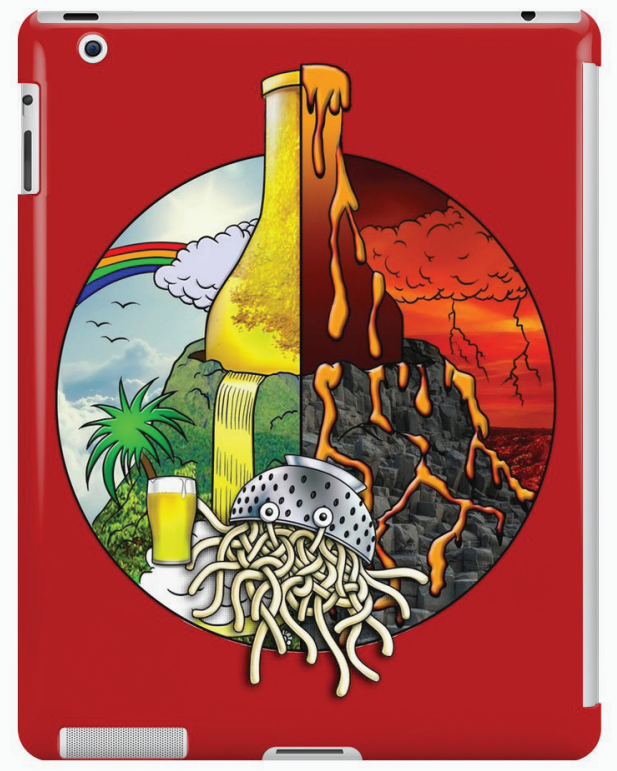

Figure 3. Heaven \& Hell Beer Fountain Volcano. Poster of the FSM Church. (C) DooodleGod/Redbubble.com.

Henderson does not forget about the ladies, because in heaven there are male strippers for the satisfaction of the saved women Pastafarians, though the latter remain invisible to non-gay men.

Instead of the traditional word Amen from Judeo-Christianity, Pastafarians use Ramen to end their prayers (Smith 2008: 7), which in this particular example is not only humorous; it also refers to the Spaghetti Monster by alluding to the Japanese noodles (see Solt 2014).

FSM followers may be guided by eight tips that clearly indicate what they should not do. It is also known as the Eight Flying Spaghetti Condiments, or Octalogue. Each of them begins with the phrase "I'd Really Rather You Didn't". For example, the third of the guidelines says:

I'd Really Rather You Didn't judge people for the way they look, or how they dress, or the way they talk, or, well, just play nice, okay? Oh, and get this through your thick heads: Woman = Person. Man = Person. SameySamey. One is not better than the other, unless we're talking about fashion and I'm sorry, but I gave that to women and some guys who know the difference between teal and fuchsia. (Henderson 2006: 78)

So, Henderson is parodying religion as a social institution. He also includes another worldview, Buddhism, which in the last decades has become popular in the West, including in the USA. As with the teachings of Prince Gautama, Pastafarianism promotes an absence of dogma (Gajewski 2016: 24), in its extreme form, including even the negation of the Spaghetti Monster itself (Sieradzan 2013: 31). Just as tantra Buddhists believe that the deity visualised in meditation is just a creation of the mind (Brunnhölzl 2009: 122), Henderson proposes that each follower should make his or her own simulacrum of the FSM. 
Henderson sees Pastafarians as having most in common with Rastafarians (Ras Tafari, Haile Selassie, Negus Neghesti ('king of kings') emperor of Ethiopia from 1930 to 1974): from similar names, to Rastafarian dreadlocks resembling curly noodles. The similarity of these two new movements is emphasised by the fact that both have been carefully constructed to have the appearances of a religion (Livraghi 2009 [2004]: 142).

\section{THE CHURCH OF THE FSM AND THE LAW: PASTAFARIANISM IN DIFFERENT COUNTRIES (SELECTED ISSUES)}

In 2011, a Pastafarian case from Vienna gained publicity when a young man contested a law that prohibits headgear in official photographs. The legal provision excluded cases in which the headgear is associated with a religion. Niko Alm presented a photograph for a new driving license showing him with a colander on his head. The Austrian explained that the colander, used for straining pasta, is religious headgear for Pastafarians. The officials refused his application, although after a court case lasting three years the decision was reversed. Since then Alm has had a driving license that shows him with a colander on his head (Hopko \& Scott \& Garrison 2018: 18-19; Maffei 2012: 491).

In Brno in 2013, Czech Pastafarian Lukáš Nový received permission for a temporary ID (valid for 30 days) with a photograph in which he wore a colander on his head. Nový argued that his religion required him to wear such a covering on his head at all times, including in photographs for documents (Barnat 2017: 318-319). At the same time, the Czech Ministry of the Interior announced that it was not possible to issue an ID with such a photograph, as the Church of the Flying Spaghetti Monster was not registered in the Czech Republic.

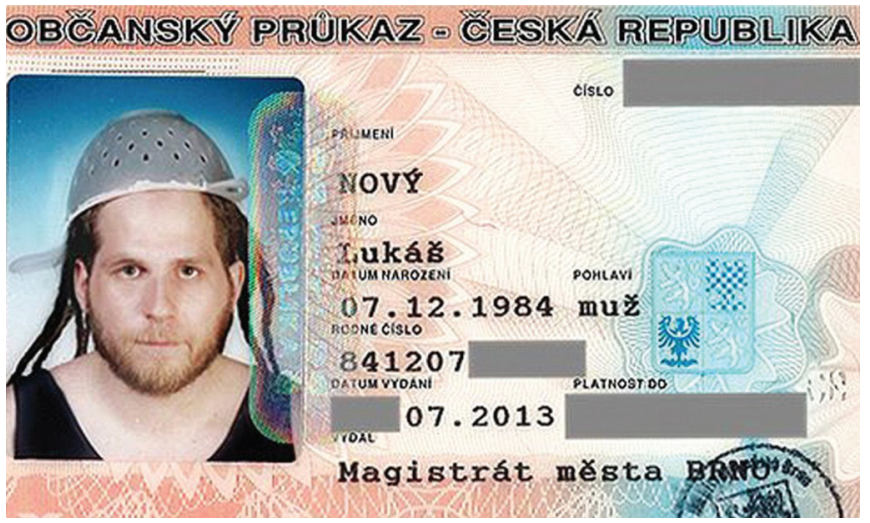

Figure 4. Lukáš Novýs ID. Source: http: / / www.dailymail.co.uk/news / article-2382465 / Im-Pastafarian-Man-claims-religion-forces-wear-sieve-head-given-permission-wearofficial-identity-card-picture.html, last accessed on 14 December 2020. 
Figure 5. Logo of the FSM Church of Australia. Source: https: / / pastafarians.org.au/, last accessed on 14 December 2020.

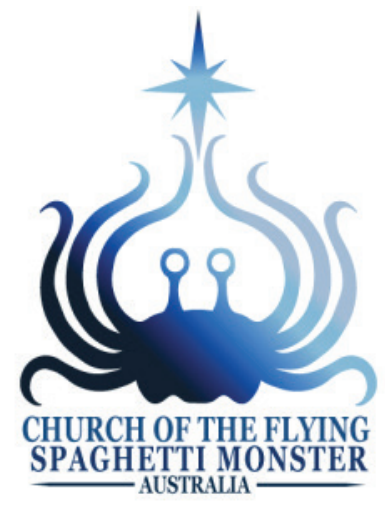

In the USA in 2014, Christopher Schaeffer, the newest member of the Pomfrett NY Town Council, swore his official oath with a colander on his head (Starratt 2016: 210). The first official marriage between two Pastafarians, Toby Ricketts and Marianna Fenn, took place in April 2016 in New Zealand, ${ }^{14}$ where the movement had been recognised as a religion a year earlier (Durrant \& Poppelwell 2017: 4). In the Netherlands the CFSM was officially recognised as a religion in 2016 (Hopko \& Scott \& Garrison 2018: 18).

In Poland Pastafarians chose an inopportune moment in political history to become active (Moddelmog-Anweiler 2017: 116). ${ }^{15}$ In August 2010 a macaroni action-happening took place in Warsaw, during the unrest that surrounded the so-called scandal of the cross. The organisers of the happening, modelled by Henderson, aimed to make demonstrators aware of the existence of other religions and so went to the Presidential Palace in Krakowskie Przedmieście Street with a bowl of pasta, which they ritually consumed among the group of protesting Catholics and atheists (Nowicki 2011: 79).

In July 2012, Polish Pastafarians formally applied for their church to be entered into the register of churches and other religious associations (Tyrała 2014: 144). During the scandal which followed the attempt to register the new religious association, two religious scholars from Kraków answered the question of whether the CFSM can be called a religion. They stated the following:

- In the individual and private domain - yes (because everyone can recognise what they like, even if it is absurd).

- In the official or formal domain, when it comes to state office, and especially the Ministry, no (because such 'recognition' then receives a social and state dimension, and above all has legal consequences); one may also suspect that the group's application for recognition as a 'religious community' is a continuation of this parody (Banek \& Czarnecki 2012). 


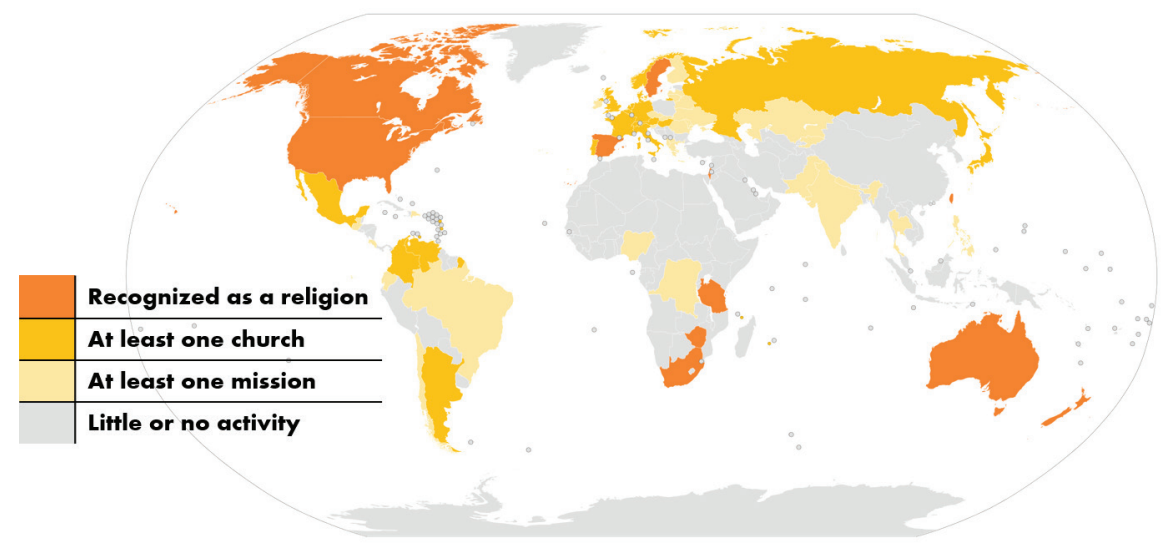

Figure 6. Recognition of Pastafarianism around the world. (C) Conquistador. Source: https:/ / commons.wikimedia.org / wiki/File:Pastafarianism_recognizing_states.svg, last accessed on 15 December 2020.

While this expert opinion was not binding on the Ministry, Minister Michał Boni refused to register the movement (Firlit 2015: 24). Nevertheless, on 8 April 2014, the Voivodship Administrative Court in Warsaw annulled the decision of the Minister of Administration and Digitisation, Michał Boni. In October 2014, Secretary of State Stanisław Huskowski issued a decision on behalf of the Minister of Administration and Digitisation, refusing to register the Church of the Flying Spaghetti Monster (Grobler 2014: 189). The Church appealed and the next hearing regarding registration took place on 28 April 2015, when the Administrative Court in Warsaw ruled in favour of the Church because the refusal was issued twice by the same official (Wyrok 2014). On 18 May 2016, the Voivodship Administrative Court in Warsaw dismissed the complaint; and the same decision was adopted by the Supreme Administrative Court in Warsaw on 19 November 2016. At present, this dispute between the 'Church' of the FSM and the Polish state remains unresolved (see Libiszowska-Żółtkowska 2016).

According to Polish religious scholars, among others Dr. Paweł Boniecki, declaration of faith in the Flying Spaghetti Monster has gained popularity among atheists and agnostics. ${ }^{16}$ There was also opposition because in the documents used for registration it was stated that a community would be established in order to profess and spread its faith, which has a system, doctrine and rituals, and requires one to register in the community (Święchowicz 2013: 60). However, on 18 November 2020, the Association of Flying Spaghetti Monster Fans was registered in the National Court Register with its seat in Gdańsk. 
Henderson gives a twofold answer to the question of contradictions in his religion: first, they aim to test the faith of believers, and secondly, without contradiction, religion could not accumulate a large number of followers (examples can be Christianity and Islam). Questions arise as to how Henderson wants to reconcile Christianity, which he considers to be the embodiment of violence, a kind of "religious Rambo" (2006: 28), with Buddhism, which is a "highly peaceful religion". In accordance with his faith, he does not propose a common prayer or meditation, but rather eating their favourite meal together. However, even with this approach we can recognise a somewhat ironic reference to the Christian feast agape, which, especially in the first centuries of Christianity, was of great importance to believers (Shackleford 2005: 86).

\section{CONCLUSION}

Even the most absurd joke does not have to be deprived of the sacred element, and vice versa, humour can appear even in serious phenomena such as religion. But is the idea of Pastafarians really religious?

An undoubted advantage of Pastafarianism is the sense of humour of its founder, as evidenced by the drawing of the skull with one eyepatch, which is the image of the pirate as a perfect believer, and the slogan Convert or Die! The official teaching of this Church says that "any content that seems ridiculous and humorous is only fortuitous" (Gajewski 2016: 24). If someone feels offended by the beliefs of the CFSM, Henderson responds that other beliefs also offend him as a follower of the FSM. However, he reserves the right not to persecute or kill others in the name of his religion, as fanatics of other religions do (2006: 65).

The FSM religion claims to respond to the challenges of the new times in which the idols of media, film, music, art, sport, etc., are justified and their fame is often as short-lived as eating a portion of pasta. The CFSM attempts to show the truth about American Christians as followers of a syncretic ideology that combines the free, subjective reading of the Bible with the unscientific hypotheses of Intelligent Design. The CFSM uses jokes and parody and even lies. However, the motivation underlying the activity in its assumption is positive. It is not only about fun but also about social criticism. FSM doctrine pokes fun at and criticises both itself and other religions. For "believers" of invented religions like the CFSM irony is an instrument that does not offer true knowledge but just shows what we do not know and that searching for the Absolute (= truth) is doomed to fail (Reece 2002: 160).

The FSM itself fits perfectly into what has long been noted by religious anthropologists and religious researchers, i.e. that the new postmodern religions 
are of a sacrophanic nature in which the rigid division of religious ideologies into sacrum and profanum has been replaced by a new sacrofanum (such as the new postmodern religions of capitalism, consumption, television, technology, football, rock, the Internet, etc.) (Sieradzan 2013: 33). By reading and analysing the Holy Scriptures of Pastafarians, we see unmistakably that the FSM has not non-sacral but rather sacrophanic attributes. Then it becomes obvious how such movements as the CFSM do not come into conflict with traditional or other forms of religiosity. They represent alternative worldview positions. We can almost certainly say that the activities of the CFSM cannot realise religious needs (Dyadushkin 2013: 14). The postmodern sacred in pop culture (and the CFSM is one form of this culture) exists as a supplement to religion (Libiszowska-Żółtkowska 2015: 15).

At present, the dispute between the CFSM and the Polish state remains unresolved. On the one hand, it is a parody bearing the banner of protest while preserving the carnivalistic, sarcastic approach to beliefs and postulates. Through laughter there is a deliverance from fear, and the possibility of a new perspective on the world around us. Although supporters of the Spaghetti Monster deny the idea of clericalisation, perhaps even subconsciously they continue to play with a variation of this theme, thereby implicating the idea of worship.

On the other hand, in such a humorous form adherents of the doctrine defend their own scientific views, the sources of which must be sought in the Age of Enlightenment. It makes a game of something sacred, which is an act of parody, and at the same time reproduces the deep subconscious ideas and desires of worship, including religious ones. The paradox of the sacrum play can be explained by the Johan Huizinga's Homo Ludens theory, which says that worship and play have a common property in that they are both a closed space separated from everyday surroundings (1998: 46-49). Inside this fenced circle is a game in which special rules apply: exclusion from everyday life and the joyful nature of the action. Fun is a different mode of action, turning the order of everyday life upside down, as with the carnival of medieval Christianity or Purim in Judaism.

The views expressed by followers of the CFSM have a visible ideological duality: when there is a need, this organisation is supposed to pretend to be a religion, while at other times the main goal is to parody and insult existing religions and religious movements, especially Christianity. In order to register as a religious association in various countries, Pastafarians proclaim that they do not want to offend anyone, and that their faith is authentic.

It seems possible to distinguish two completely different categories: the religion of laughter, and mocking religion. The first is intended to amuse believers while not offending other religious systems or ridiculing their doctrines or forms 
of worship. Such religions of laughter do not impersonate real or traditional belief systems with the intention of parodying or compromising those religions. An example of this may be the Feast of Fools, rites and rituals which were not subversive to the Christian tradition. The Feast of Fools took its name not from fools who rebelled against God, but from fools who are loved by God for their lowly status (Harris 2011: 68). Mocking religions, including the CFSM, are mainly parodies of real beliefs, which they ridicule.

In FSM 'doctrine', it is easy to find an aversion to religion in general, and most of its followers are atheists (Pachciarz 2015: 21). It seems that humour in the CFSM has a subversive character. The CFSM mainly opposes Christianity, but it also critically refers to selected structural elements of other religions to hide some of its real goals, high on the list of which is striking at the religious tradition of the West, as found in Christianity (see the critique of the Our Father and Hail Mary prayers in Kamiński 2015: 45-46). It should be said that the CFSM was created only to oppose Intelligent Design, not to profess and spread a faith. The CFSM is a form of joke in which there is an evident intention to ridicule the dogmas of Christianity and some other faith systems (to a lesser extent), and to parody the cult, doctrine, and rites of the authentic form of religiosity. This is not a proper, genuine mode of religious expression.

\section{NOTES}

1 According to some of the most liberal approaches, religion is everything that a human considers as a religion.

${ }^{2}$ In the literature Henderson is sometimes called the first prophet of the CFSM. Such a statement is not entirely correct, because the first prophet of the 'Church' for Pastafarians is Captain Mosey.

3 The story began in 1999 when the Kansas Board of Education set new standards in education that did not contain references to the age of the Earth, the Big Bang theory or the theory of evolution. What's more, knowledge about the latter was not required in school exams, which meant that students were not being made aware of its assumptions. Finally, in 2005 Intelligent Design found its place next to the theory of evolution in the biology programme.

4 This being was described in one of the American newspapers as "a googly-eyed blob of noodles grasping two meatballs".

5 Another mockery of traditional religions - both Judaism and Christianity - the Spaghetti Monster did this, however, faster than the Jewish god, i.e. in five days.

${ }^{6}$ In three months, this web page received nearly two million hits a day and has been commented on in major print media, as well as in various online chats, discussion forums and blogs. 
7 Pastafarians even have a kind of sacramental bread, Sacrilicious (Latin hostia), reminiscent of that used in the Catholic liturgy. Admittedly, this is not, of course, a consecrated host, in addition to which on every wafer is the likeness of the Spaghetti Monster.

8 Another joke religion that ridicules the idea of creationism is Last Thursdayism. See: Jennings 2015: 23; Lagemaat 2015 [2005]: 286.

9 To support his thesis with evidence, Henderson presented a graph of statistical data on the average annual temperature on Earth over the last few centuries against the declining number of pirates. This is why one of the slogans of the CFSM is 'Stop Global Warming, Become a Pirate'.

10 There is even a special feast day in the CFSM calendar, Talk Like a Pirate Day, 19 September, when everyone is encouraged to speak in a pirate accent. Other festivals are Ramendan (in reference to the Muslim Ramedan) and Pastover (in reference to the Passover) (see Chryssides 2012: 92).

${ }^{11}$ Pastafarians are required to wear a full pirate costume or at least an eye-patch, and every Friday is a day off, which should be celebrated by eating a bowl of spaghetti.

1295 percent of human DNA is shared with monkeys, and 99.9 percent with pirates.

13 The image of the volcano could be 'borrowed' from the covers of L. Ron Hubbard's Dianetics.

${ }^{14}$ In all fairness, it should be noted that the first Pastafarian wedding in Europe took place in the Polish city of Łódź in 2014, but as the movement is not considered a religion in Poland, the event was not noticed by the world's media (see La Capitale 2018).

${ }^{15}$ Poland is an example of a European country where there is a so-called 'endorsed church' phenomenon, i.e. the preference for a certain church that is not defined in a legal way but is traditionally associated with the national identity.

${ }^{16}$ Since 2008 the Missouri State CFSM has sponsored Skeptikon, the largest atheist convention in the US Midwest, although Henderson does not claim to be an atheist (see Chryssides 2012: 92). The Pastafarians themselves define atheism as "the simple consequence of FSMism".

\section{REFERENCES}

Aarde, Andries Gideon van 2013. Caught in the Snare of She'ol, But Dew Gives Life to Dust. In: J. Harold Ellens (ed.) Heaven, Hell, and the Afterlife: Eternity in Judaism, Christianity, and Islam. Volume 1: End Time and Afterlife in Judaism. Santa Barbara \& Denver \& Oxford: Praeger, pp. 35-42.

Bakhtin, Mikhail 1984. Rabelais and His World. Transl. by Helene Iswolsky. Bloomington: Indiana University Press. Available at https://monoskop.org/images/7/70/Bakhtin_ Mikhail_Rabelais_and_His_World_1984.pdf, last accessed on 14 December 2020. 
Banek, Kazimierz \& Czarnecki, Piotr 2012. Ekspertyza w kwestii: Czy w świetle przedstawionych dokumentów można uznać Kościót Latającego Potwora Spaghetti za wspólnotę religijna. [Expert Opinion on the Issue: Can the Church of the Flying Spaghetti Monster Be Considered a Religious Community in the Light of the Presented Documents.] Available at https://klps.pl/wp-content/uploads/2020/05/ ekspertyza.pdf, last accessed on 14 December 2020.

Barnat, Damian 2017. Sekularyzm polityczny a spór o przekonania sumienia. [Political Secularism and the Dispute over Conviction of Conscience.] Roczniki filozoficzne [Philosophical Annals], Vol. 65, No. 4, pp. 293-323. Available at https://www.pdcnet. org/rf/content/rf_2017_0065_0004_0293_0323, last accessed on 14 December 2020.

Beckford, James A. \& Demerath, Jay 2007. The SAGE Handbook of the Sociology of Religion. Los Angeles \& London \& New Delhi \& Singapore: SAGE Publications.

Beckwith, Francis J. 2003. Law, Darwinism, and Public Education: The Establishment Clause and the Challenge of Intelligent Design. Lanham \& Boulder \& New York \& Oxford: Rowman \& Littlefield Publishers, Inc.

Brunnhölzl, Karl 2009. Luminous Heart: The Third Karmapa on Consciousness, Wisdom, and Buddha Nature. New York: Snow Lion Publications.

Burde, Mark 2010. The Parodia sacra Problem and Medieval Comic Studies. In: A. Classen (ed.) Laughter in the Middle Ages and Early Modern Times: Epistemology of a Fundamental Human Behavior, Its Meaning, and Consequences. Berlin \& New York: De Gruyter, pp. 215-242.

Chidester, David 2005. Authentic Fakes: Religion and American Popular Culture. Berkeley \& Los Angeles \& London: University of California Press.

Chryssides, George D. 2012 [2001]. Historical Dictionary of New Religious Movements. Lanham \& Toronto \& Plymouth: The Scarecrow Press, Inc.

Cusack, Carole M. 2010. Invented Religions: Imagination, Fiction and Faith. Sydney: Routledge.

Cusack, Carole M. 2012. Media Coverage of Scientology in the United States. In: D. Winston (ed.) The Oxford Handbook of Religion and the American News Media. Oxford \& New York: OUP, pp. 303-318.

Davies, Christie 1998. Jokes and their Relations to Society. Berlin \& New York: Mouton de Gruyter.

Dooling, Richard 2008. Rapture for the Geeks: When AI Outsmarts IQ. New York: Crown Archetype.

Durrant, Russil \& Poppelwell, Zoe 2017. Religion, Crime and Punishment: An Evolutionary Perspective. Cham: Springer.

Dyadushkin 2013 = Diadiushkin, Aleksandr. Religioznyi opyt $\mathrm{v}$ kontekste akademicheskoi interpretatsii psevdoreligii. [Religious Experience in the Context of the Aacademic Interpretation of Pseudo-religions.] Sociosfera [Sociosphere], No. 2, pp. 11-16. Available at http://sociosphera.com/files/conference/2013/Sociosphere_2-13/1116_a_m_dyadyushkin.pdf, last accessed on 14 December 2020.

Fang, Cardinal 2014. The Pastafarian Loose Canon. Raleigh: Lulu.

Firlit, Elżbieta 2015. Procedury rejestracji podmiotów wyznaniowych i zmiany w strukturze wyznaniowej polskiego społeczeństwa po 1989 roku. [Procedures for the Registration of Religious Subjects and Changes in the Religious Structure 
of Polish Society after 1989.] Kwartalnik Kolegium Ekonomiczno-Spotecznego Studia i Prace [Quarterly of College of Economics and Social Studies and Works], No.1, pp. 13-33. Available at https://ssl-kolegia.sgh.waw.pl/pl/KES/czasopisma/ kwartalnik/Documents/EF21.pdf, last accessed on 14 December 2020.

Gajewski, Mariusz 2016. Fatszywi nauczyciele: Sekty dzisiaj. [False Teachers: Sects Today.] Poznań: MONUMEN.

Geoffroy, Martin 2012. Hyper-real Religion Performing in Baudrillard's Integral Reality. In: A. Possamai (ed.) Handbook of Hyper-real Religions. Leiden \& Boston: BRILL, pp. 23-35.

Gilhus, Ingvild Sælid 2004 [1997]. Laughing Gods, Weeping Virgins: Laughter in the History of Religion. London \& New York: Routledge.

Grobler, Adam 2014. Hermeneutyka Poppera a problem niejednomyślności. [Popper's Hermeneutics and the Problem of Unanimity.] Przeglad Filozoficzny - Nowa Seria [Philosophical Review - New Series], No. 4, pp. 183-192. Available at http:// journals.pan.pl/pfns/106086\#tabs, last accessed on 14 December 2020.

Harris, Max 2011. Sacred Folly: A New History of the Feast of Fools. Ithaca \& London: Cornell University Press.

Henderson, Bobby 2006. The Gospel of the Flying Spaghetti Monster. New York: Villard. Hopko, Joel \& Scott, Gregory M. \& Garrison, Stephen M. (eds.) 2018. The Religion and Theology: Student Writer's Manual and Reader's Guide. Lanham \& Boulder \& New York \& London: Rowman \& Littlefield.

Huizinga, Johan 1998. Homo ludens. Zabawa jako źródło kultury. [Homo Ludens: Fun as a Source of Culture.] Warszawa: Czytelnik.

Jennings, Byron K. 2015. In Defense of Scientism: An Insider's View of Science. Vancouver: Byron Jennings.

Kamiński, Ireneusz 2015. Organizacja Kościoła Latającego Potwora Spaghetti, jako typowa religia prześmiewcza. [Organisation of the Church of the Flying Spaghetti Monster as a Typical Mocking Religion.] In: J. Perszon \& A. Lisiecka-Bednarczyk \& I. Kamiński (eds.) Manipulacja, sekty i alternatywne formy religijności $w$ kierunku profilaktyki społecznej. Tom VIII. Kontrowersyjne zjawiska i grupy. [Manipulation, Sects and Alternative Forms of Religiousness - Towards a Social Prevention. Vol. VIII. Controversial Phenomena and Controversial Groups.] Toruń \& Wrocław: IKONA, pp. 35-60.

Kozintsev, Alexander 2015. Riveted: The Science of Why Jokes Make Us Laugh, Movies Make Us Cry, and Religion Makes Us Feel One with the Universe. The Humorous Times, Vol. 28, No. 1, pp. 4-6.

La Capitale 2018. Proste jak spaghetti. [Simple as Spaghetti.] Dwutygodnik Forum [Biweekly Magazine Forum]. Available at https://forumdwutygodnik.pl/ artykuly/1659206,1,proste-jak-spaghetti.read, last accessed on 14 December 2020.

Lagemaat, Richard van de 2015 [2005]. Theory of Knowledge for the IB Diploma. Cambridge: Cambridge University Press. Available at https://issuu.com/ cupeducation/docs/theory_of_knowledge_for_the_ib_dipl_ac2aa4b704af95, last accessed on 14 December 2020.

Laude, Patrick 2005. Divine Play, Sacred Laughter, and Spiritual Understanding. New York \& Basingstoke: Palgrave Macmillan. 
Libiszowska-Żółtkowska, Maria 2015. Resacralisation in Postmodern Culture: New Developments of Religion and Spirituality. Przeglad Religioznawczy - The Religious Studies Review, No. 4, pp. 3-17. Available at http://www.ptr.edu.pl/ images/PR_ang_2015/1_Maria_Libiszowska_Resacralisation.pdf, last accessed on 14 December 2020.

Libiszowska-Żółtkowska, Maria 2016. Homo religiosus: Teoria wyjaśniająca kazus pastafarian. [Homo Religiosus: The Theory Explaining the Case of Pastafarians.] In: S.H. Zaręba \& I. Borowik (eds.) Tradycja i innowacja $w$ polu refleksji socjologii religii. [Tradition and Innovation in Sociology of Religion.] Warszawa: Kontrast, pp. $247-260$.

Limelie 2014. 90\% miłości i 10\% makaronu - kim są pastafarianie? [90\% Love and 10\% Pasta - Who Are the Pastafarians?] Kon Kościuszki [Kosciuszko's Horse], No. 7, pp. 21-22. Available at http://www.1lo.wlodawa.pl/images/Dokumenty/ KonKosciuszki/7\%20numer\%20konia\%20dwa.pdf, last accessed on 11 December 2020.

Livraghi, Giancarlo 2009 [2004]. The Power of Stupidity. Pescara: Monti \& Ambrosini SRL.

Lochrie, Karma 2016. Nowhere in the Middle Ages. Philadelphia: University of Pennsylvania Press.

Maffei, Maria Clara 2012. The Vegetarian Diet in Prison: A Human Right? The Case of Jakóbski v. Poland. In: N. Boschiero \& T. Scovazzi \& C. Pitea (eds.) International Courts and the Development of International Law: Essays in Honour of Tullio Treves. The Hague: Springer Science \& Business Media, pp. 489-496. Available at https://www.springer.com/gp/book/9789067048934, last accessed on 14 December 2020.

McDonald, Paul 2012. The Philosophy of Humour. Penrith: Humanities-Ebooks.

Mikhelson, Ol'ga 2018. Sakralizatsiia populiarnogo: Metodologicheskie podkhody $\mathrm{k}$ issledovaniiu religion-like phenomena $\mathrm{v}$ sovremennom religiovedenii. [The Sacralization of the Popular: Methodological Approaches to the Study of Religionlike Phenomena in Modern Religious Studies.] Vestnik Sankt-Peterburgskogo universiteta: Filosofiia $i$ konfliktologiia [Bulletin of St. Petersburg State University: Philosophy and Conflictology], Vol. 34, No. 1, pp. 122-137. https:// doi.org/10.21638/11701/spbu17.2018.112.

Moddelmog-Anweiler, Emilia 2017. Religia w przestrzeni życia publicznego w regionach Europy Środkowej: Cechy modelu środkowoeuropejskiego. [Religion in the Space of Public Life in the Regions of Central Europe: Features of the Central European Model.] Politeja, No. 46, pp. 103-139. Available at https://www.jstor. org/stable/26213950?seq=1, last accessed on 14 December 2020.

Nowicki, Mateusz 2011. Joke religions jako nowy model religijności współczesnej. [Joke Religions as a New Model of Modern Religiosity.] Ex Nihilo: periodyk młodych religioznawców [Ex Nihilo: A Periodical of Young Religious Scholars], No. 2, pp. 57-90. Available at http://www.exnihilo.religioznawstwo.uj.edu.pl/exnihilo-6-2011, last accessed on 14 December 2020.

Obadia, Lionel 2015. When Virtuality Shapes Social Reality: Fake Cults and the Church of the Flying Spaghetti Monster. Online Heidelberg Journal of Religions on the 
Internet, No. 8, pp. 115-128. Available at https:/heiup.uni-heidelberg.de/journals/ index.php/religions/article/view/20327/14121, last accessed on 14 December 2020.

Pachciarz, Adrian 2015. Kościół Latającego Potwora Spaghetti (FSM) jako przykład religii prześmiewczej. [The Church of the Flying Spaghetti Monster (FSM) as an Example of Mocking Religion.] In: J. Perszon \& A. Lisiecka-Bednarczyk \& I. Kamiński (eds.) Manipulacja, sekty i alternatywne formy religijności $w$ kierunku profilaktyki społecznej. Tom VIII. Kontrowersyjne zjawiska i grupy. [Manipulation, Sects and Alternative Forms of Religiousness: Towards a Ssocial Prevention. Vol. VIII. Controversial Phenomena and Controversial Groups.] Toruń \& Wrocław: IKONA, pp. 11-34.

Pawluczuk, Włodzimierz 1990. Wiara a życie codzienne. [Faith and Everyday Life.] Kraków: Miniatura.

Pittman, Craig 2016. Oh, Florida! How America's Weirdest State Influences the Rest of the Country. New York: St. Martin's Press.

Reece, Gregory L. 2002. Irony and Religious Belief. Tübingen: Mohr Siebeck.

Rynkiewicz, Justyna 2012. Kognitywne spojrzenie na poczucie humoru. [The Cognitive Views on a Sense of Humour.] Via Mentis, Vol. 1, No. 1, pp. 85-98. Available at http://viamentis.umcs.lublin.pl/wp-content/uploads/2013/02/Justyna-RynkiewiczKognitywne-spojrzenie-na-poczucie-humoru.pdf, last accessed on 15 December 2020.

Saroglou, Vassilis 2002. Religion and Sense of Humor: An A Priori Incompatibility? Theoretical Considerations from a Psychological Perspective. Humor: International Journal of Humor Research, Vol. 15, No. 2, pp. 191-214. http://dx.doi.org/10.1515/ humr.2002.011.

Shackleford, John M. 2005. God as Symbol: What Our Beliefs Tell Us. Lanham \& Oxford: University Press of America.

Sieradzan, Jacek 2013. Pastafarianizm: religia czy parodia religii? Wokół odmowy uznania w Polsce pastafarian za wspólnotę religijną. [Pastafarianism: Religion or Parody of Religion? Around the Refusal to Recognize Pastapharians in Poland as a Religious Community.] Humaniora. Czasopismo Internetowe [Humaniora. Internet Magazine], No. 4, pp. 29-36. Available at http://humaniora.amu.edu. $\mathrm{pl} /$ archiwum, last accessed on 14 December 2020.

Smarsh, Sarah 2010. It Happened in Kansas: Remarkable Events that Shaped History. Guilford: Rowman \& Littlefield.

Smith, Jon 2008. God Speaks! The Pastafarian Quatrains: A Scholarly Analysis and Critique of the Flying Spaghetti Monster. Raleigh: Lulu.

Solt, George 2014. The Untold History of Ramen: How Political Crisis in Japan Spawned a Global Food Craze. Berkeley \& Los Angeles \& London: University of California Press.

Starratt, Valerie G. 2016. Evolutionary Psychology: How Our Biology Affects What We Think and Do. Santa Barbara: ABC-CLIO.

Święchowicz, Małgorzata 2013. Pasta, czyli religia. [Pasta, or Religion.] Newsweek, No. 5 , p. 60.

Tiaglova, Maria 2014. Karnaval'nost' i igra v sakral'noe v igrovykh formakh protesta. [Carnival and Sacred Play in Game Forms of Protest.] In: V.V. Abramenkova 
\& I.L. Kirillov \& S.Yu. Devyatych (eds.) A Game and Toys in the History and Culture, Development and Eeducation: Materials of the III International Scientific Conference on April 1-2, 2014, Prague, CZ. Prague: Vědecko vydavatelské centrum "Sociosféra-CZ", pp. 17-21. Available at http://www.sociosphera.com/ files/conference/2014/k-04_01_14.pdf, last accessed on 14 December 2020.

Tyrała, Radosław 2014. Piętno a (de)materializacja kultury niereligijnej. [The Stigma and (De)materialization of Non-religious Culture.] Studia Humanistyczne AGH [Contributions to Humanities], Vol. 13, No. 2, pp. 135-152. Available at https:// journals.agh.edu.pl/human/issue/view/204/showToc, last accessed on 14 December 2020.

Ulmer, Gregory L. 1985. The Object of Post-Criticism. In: H. Foster (ed.) Postmodern Culture. London: Pluto Press, pp. 83-110.

Wyrok 2014 = Wyrok Wojewódzkiego Sacdu Administracyjnego $w$ Warszawie $z$ dnia 28 kwietnia 2015 r. sygn. akt I SAM/a 381/15 o uchyleniu decyzji Ministra Administracji i Cyfryzacji z dnia 22 grudnia 2014 r. [Judgment of Voivodship Administrative Court in Warsaw of April 28, 2015. sygn. akt I SAM/a 381/15 on Repealing the Decision of the Minister of Administration and Digitization of December 22, 2014.]

Siarhei A. Anoshka is a PhD student and Junior Lecturer at the Department of Religious Dialogue at the Faculty of Theology, Cardinal Stefan Wyszyński University in Warsaw, Poland. His main research interests lie in the field of new religious movements, sociology of religion, contemporary Catholic theology, and geopolitics. He has written a range of articles and chapters on the Bahá'i Faith, the Church of Scientology, and the Church of Jesus Christ of Latter-day Saints. His current research focuses on charisma and authority in new religious movements.

anoshka@email.ua 